\title{
Tannins in the Treatment of Diabetic Neuropathic Pain: Research Progress and Future Challenges
}

\author{
Norsuhana Omar ${ }^{1}$, Che Aishah Nazariah Ismail ${ }^{1}$ and Idris Long $^{2 *}$ \\ ${ }^{1}$ Department of Physiology, School of Medical Sciences, Health Campus, Universiti Sains Malaysia, Kubang Kerian, Malaysia, \\ ${ }^{2}$ Biomedical Science programme, School of Health Sciences, Health Campus, Universiti Sains Malaysia, Kubang Kerian, Malaysia
}

OPEN ACCESS

Edited by:

Rajeev K. Singla,

Sichuan University, China

Reviewed by:

Santina Chiechio,

University of Catania, Italy

Nisar Ahmad,

University of Peshawar, Pakistan

${ }^{*}$ Correspondence:

Idris Long

idriskk@usm.my

Specialty section:

This article was submitted to

Ethnopharmacology,

a section of the journal

Frontiers in Pharmacology

Received: 31 October 2021

Accepted: 15 December 2021

Published: 10 January 2022

Citation:

Omar N, Ismail CAN and Long I (2022) Tannins in the Treatment of Diabetic Neuropathic Pain: Research Progress and Future Challenges.

Front. Pharmacol. 12:805854. doi: 10.3389/fphar.2021.805854
Diabetes mellitus and its consequences continue to put a significant demand on medical resources across the world. Diabetic neuropathic pain (DNP) is a frequent diabetes mellitus chronic microvascular outcome. Allodynia, hyperalgesia, and aberrant or lack of nerve fibre sensation are all symptoms of DNP. These clinical characteristics will lead to worse quality of life, sleep disruption, depression, and increased mortality. Although the availability of numerous medications that alleviate the symptoms of DNP, the lack of long-term efficacy and unfavourable side effects highlight the urgent need for novel treatment strategies. This review paper systematically analysed the preclinical research on the treatment of DNP using plant phytochemicals that contain only tannins. A total of 10 original articles involved in in-vivo and in-vitro experiments addressing the promising benefits of phytochemical tannins on DNP were examined between 2008 and 2021. The information given implies that these phytochemicals may have relevant pharmacological effects on DNP symptoms through their antihyperalgesic, anti-inflammatory, and antioxidant properties; however, because of the limited sample size and limitations of the studies conducted so far, we were unable to make definitive conclusions. Before tannins may be employed as therapeutic agents for DNP, more study is needed to establish the specific molecular mechanism for all of these activities along the pain pathway and examine the side effects of tannins in the treatment of DNP.

Keywords: diabetes mellitus, plant phytochemicals, tannins, diabetic neuropathic pain (DNP), preclinical

\section{INTRODUCTION}

Diabetic neuropathic pain (DNP) is the most prevalent diabetes complication, affecting more than half of patients, and is associated with increased morbidity and mortality (Feldman et al., 2017). Tingling, burning, sharp, shooting, and lancinating, as well as electric shock sensations, are all symptoms of DNP. These signs lead to diminished daily routines, higher unemployment rates, sleep disruption, stress and mental health problems, physical co-morbidities, and even amputation (Gylfadottir et al., 2019). The pathogenesis of DNP is not fully understood. Several theories have been proposed to explain the pain associated with diabetic neuropathy, including changes in the blood vessels that supply the peripheral nerves; a neuroinflammation process accompanied by glial cell activation; changes in sodium and calcium channel expression; and, more recently, central pain mechanisms, including increased thalamic vascularity and an imbalance of the facilitatory/inhibitory pathways (Tesfaye et al., 2013).

The molecular mechanism of DNP might also be related to an imbalance in the generation of oxidative stress and antioxidant activity. Prolonged hyperglycemia causes glucotoxicity, which 
impairs several biological metabolome pathways such as the polyol, hexosamine, poly (ADP-ribose) polymerase (PARP), protein kinase $\mathrm{C}(\mathrm{PKC})$ and generation of the advanced glycation end product (AGE) (Ab Hamid et al., 2021). These processes result in the increased formation of free radicals such as hydrogen peroxide $\left(\mathrm{H}_{2} \mathrm{O}_{2}\right)$, nitric oxide (NO), and superoxide anion (O2-), which cause cellular damage (Vincent et al., 2004). Hyperglycemia also activates inflammatory signalling pathways, which excrete a variety of mediators that aggravate the situation and contribute to the development of DNP. Following chronic hyperglycemia, the persistent generation of pro-inflammatory insults such as TNF$\alpha$ and IL- $1 \beta$, as well as oxidative stress markers, activates Tolllike receptors (TLRs) (Lawrence, 2009). As a result, these mechanisms translocate Nuclear Factor kappa-light-chainenhancer $\beta$ (NF-K $\beta$ ) into nuclei and activate the expression of NF-K $\beta$-dependent genes such pro-IL-1 $\beta$, pro-IL-18, and Nod-like receptor protein 3 (NLRP3). Increased NF-K $\beta$ activation causes a rise in the creation of additional proinflammatory and immunological cells, such as T-cells, which further destroys the cells (Liu et al., 2017). Furthermore, a study has revealed that non-neuronal cells such as microglia and astrocytes have a role in the pathogenesis of DNP in a hyperglycemic environment (Wang et al., 2014). The glialneuron crosstalk generates pathological pain in DNP, including allodynia and hyperalgesia, by releasing a variety of inflammatory mediators (Ismail et al., 2020).

Only three drugs are currently authorised in the United States by Food and Drug Administration (FDA) to treat DNP, which are duloxetine, a selective serotonin and norepinephrine reuptake inhibitor, pregabalin, an anticonvulsant, and tapentadol, a dual-action opioid receptor agonist and norepinephrine reuptake inhibitor (Freeman, 2013). All these treatments reduce pain by $30-50 \%$ but are limitedly prescribed because of their side effects. Therefore, natural products from plant secondary metabolites are now widely used to treat various chronic illnesses due to their low toxicity and high efficacy (Uddin et al., 2020).

Tannins are high-molecular-weight polyphenolic compounds found in a variety of plant species. Tannins bind to proteins and other chemical molecules, such as amino acids and alkaloids, and cause them to precipitate. The two most common tannin types are hydrolysable tannins and condensed tannins. Examples of hydrolysable tannins are gallic and ellagic acid. Whereas condensed tannins are gallocathecin, epigallocathecin, proanthocynidins and procynidin B2 (Laddha and Kulkarni, 2019). Tannins can be found in coffee, tea, wine, grapes, apricot, barley, peaches, dry fruits, mint, basil, rosemary, pomegranate, strawberries, amla, clove, rice, oat, rye, and other foods. Tannins are gaining popularity these days due to the health advantages linked with their antioxidant qualities (Ajebli and Eddouks, 2018).

Despite the health benefits of tannins, there are no systematic evaluations on tannins' potential for treating DNP. Therefore, this study examined and synthesised research on tannins on DNP in in-vivo and in-vitro experiments to determine their antinociceptive effects in neuropathic pain models.

\section{MATERIALS AND METHODS}

For this systematic search, we developed a search strategy to identify relevant works of literature. This search strategy was limited to English articles. It used different combinations of the following keywords: neuropathic pain, plants metabolite, natural product, tannins, gallic acid, ellagic acid, epigallocatechin, and proanthocynidins in three databases: Scopus, PubMed, and Google Scholar.

The databases were combed for studies that took place between 2008 and August 2021. Only DNP studies that included in-vivo and in-vitro experiments were included, as well as the use of compounds containing only phytochemical tannins (gallic acid, ellagic acid, epigallocatechin, and proanthocynidins) derived from medicinal plants for treatment. Studies were excluded according to the following exclusion criteria: studies in human beings and non-diabetic neuropathic pain, studies using polyphenol that contain another polyphenol such as coumarins and flavonoid, extracts or mixtures (as essential oils), review articles, meta-analyses, abstracts, conference proceedings, editorials/letters and case reports as shown in Figure 1 (PRISMA statement).

\section{RESULTS}

A total of 222 abstracts/citations were identified from the electronic search for preliminary review. After the removal of duplicates and screening for relevant titles and abstracts, a total of 27 articles were submitted for a full-text review. Ten articles fulfilled the inclusion and exclusion criteria established. In most articles analysed, the substances used were purchased commercially (70\%). Only three studies were conducted as compounds isolated from plants (30\%). Table 1 and Table 2 shows the summary of experimental studies using tannins phytochemical in DNP and composition of substances used.

\section{DISCUSSION}

Male rats from various species such as Swiss albino (Abo-Salem et al., 2020), Sprague-Dawley (Ding et al., 2014; Addepalli and Suryavanshi, 2018), Wistar (Cui et al., 2008; Piaulino et al., 2013; Raposo et al., 2015) and albino Wistar (Baluchnejadmojarad and Roghani, 2012) were used in the majority of the studies as DNP models. Two more studies used male Swiss Webster (Raafat and Samy, 2014) and C57BL/6J mice (Jin et al., 2013), while two investigations used cell cultures of dorsal root ganglion neuron (Zhang et al., 2018) and RSC96 Schwann cells (Ding et al., 2014) as a model for DNP. The most common technique for inducing diabetes and simulating the DNP is a single dose of streptozotocin (STZ) injection into the intraperitoneal and the tail vein. Other substances, such as alloxan, have also been used to cause diabetes. Mostly the rats or mice induced to be diabetic in these studies were type 1 diabetes. Diabetes can also be generated by changes in diet, such as a high carbohydrate and fat diet, which can lead to type 2 diabetes (Jin et al., 2013; Ding et al., 2014). However, we did 


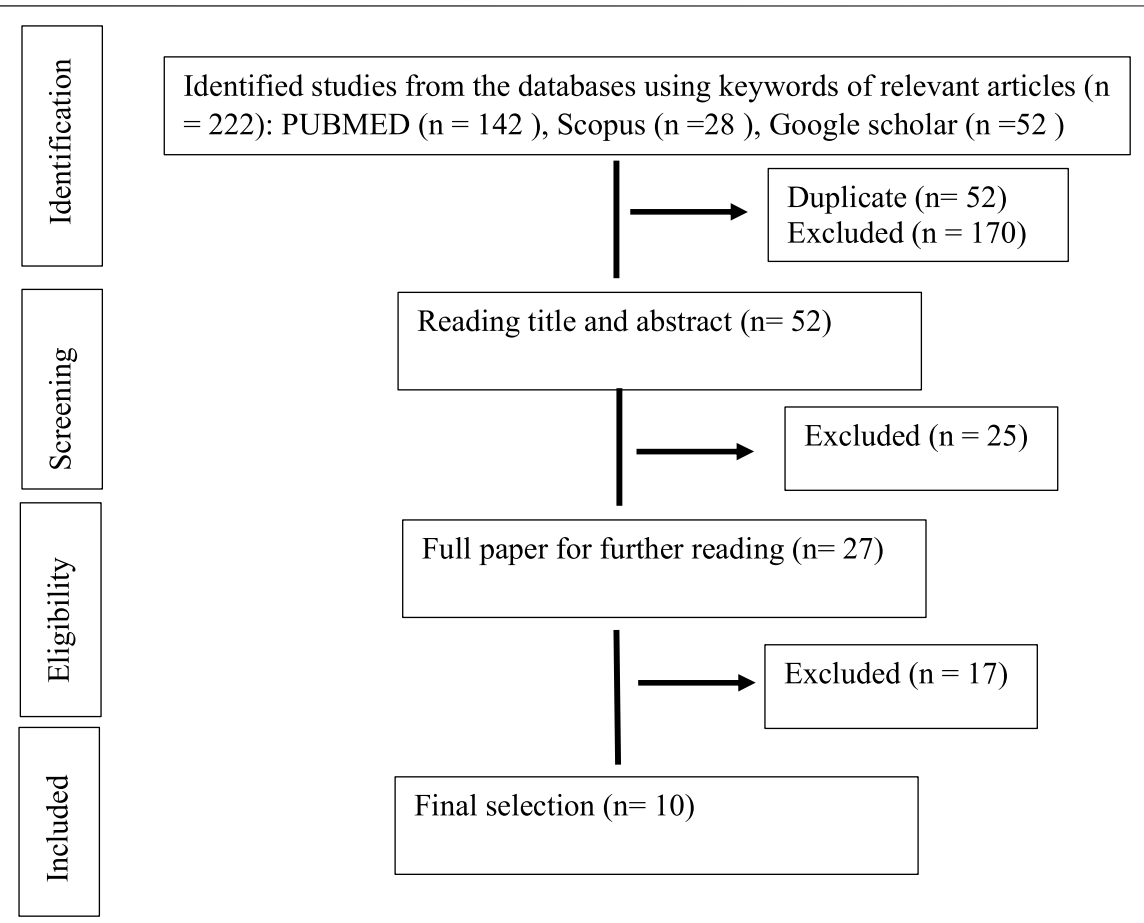

FIGURE 1 | Search and selection results (PRISMA statement).

not find a study to investigate the effects of phytochemical tannins on DNP using genetic modification in rats or mice.

Hyperalgesia and allodynia are symptoms of DNP linked to long-term hyperglycemia, insulin insufficiency or resistance, and dyslipidemia (Kim and Feldman, 2012). Many of the diabetes medications developed aimed to correct these problems and restore the situation by reducing the blood glucose level and increasing body weight. It has been demonstrated that taking (-) -Epigallocatechin-3-O-gallate (EGCG) orally at a dose of $25 \mathrm{mg} / \mathrm{kg}$ for 5 weeks can lower serum blood glucose levels, improve serum lipid profiles, and increase body weight (AboSalem et al., 2020). Other studies were done by Addepalli and Suryavanshi (2018) used catechin, Raafat and Samy (2014) used Punica granatum L. (Lythraceae) extract, and Baluchnejadmojarad and Roghani (2012) used EGCG have validated the benefits of phytochemical tannins in lowering blood glucose and increasing body weight. However, other investigations using EGCC and stem bark extracts of Cenostigma macrophyllum Tul (Fabaceae) on male Wistar rats by Raposo et al. (2015) and Piaulino et al. (2013) failed to restore blood glucose levels and body weight gain. A study by Cui et al. (2008) used grape seed proanthocynidins on male Wistar rats and found that they could lower HbA1c and AGEs while increasing body weight but not blood glucose levels. In high glucose dorsal root ganglia (DRG) culture, administration of Proanthocyanidin B2 $(10 \mu \mathrm{g} / \mathrm{ml})$ restored the neurotoxic effect generated by glucose challenge (Zhang et al., 2018). The primary afferent neurons in the DRG are altered by incubated with high glucose concentration. This glucose challenge causes hyperglycemia, which inhibits neuronal development and causes oxidative stress and mitochondrial malfunction, leading to apoptotic cell death in DRG (Chowdhury et al., 2010; Akude et al., 2011).

Furthermore, phytochemical tannin treatment did not much affect blood glucose levels or body weight gain in a type 2 DNP animal model. Ding et al. (2014) observed that grape seed proanthocynidins did not affect blood glucose levels or body weight in male Sprague-Dawley rats fed with a highcarbohydrate, high-fat diet with two injections of $25 \mathrm{mg} / \mathrm{kg}$ of STZ. Jin et al. (2013) discovered that providing a high-fat diet to male C57BL/6J mice and given Vitis vinifera L. (Vitaceae) grape seed extract (VVE) did not lower blood glucose levels while simultaneously not increasing body weight. Insulin resistance and insulin insufficiency are two characteristics of type 2 diabetes. The natural mechanism of metabolic dysfunctions in human type 2 diabetes would be precisely mimicked by feeding the animal a high carbohydrate and high-fat diet followed by a low-dose STZ injection (Srinivasan et al., 2005). Insulin resistance, one of the critical characteristics of type 2 diabetes, is triggered by a high carbohydrate and fat diet. Low-dose STZ injections can cause a modest decrease in insulin production, similar to the latter stages of type 2 diabetes (Stott and Marino, 2020). However, the benefit of phytochemical tannin treatment on hyperglycemia and body weight in the DNP animal model is equivocal, with findings varying depending on the rat species, types of diabetes, DNP induction techniques, and substances delivery procedures.

Phytochemical tannins have been shown to have neuroprotective benefits in diabetic complications due to their anti-inflammatory and antioxidant characteristics (Meng et al., 2019). When EGCG was given orally at a $25 \mathrm{mg} / \mathrm{kg}$ dose for 5 weeks, inflammatory markers such as plasma IL-6, NO NO, and 
TABLE 1 | Characteristic of included studies.

\begin{tabular}{|c|c|c|c|c|c|c|}
\hline $\begin{array}{l}\text { Compound, plants } \\
\text { species, source, } \\
\text { concentration }\end{array}$ & $\begin{array}{c}\text { Tannins } \\
\text { constituents }\end{array}$ & $\begin{array}{c}\text { Type of } \\
\text { study, animals } \\
\text { and diabetic } \\
\text { model }\end{array}$ & $\begin{array}{l}\text { Control group } \\
\text { and duration } \\
\text { of treatment }\end{array}$ & $\begin{array}{l}\text { Daily dose } \\
(\mathrm{mg} / \mathrm{kg}) \text { and } \\
\text { routes of } \\
\text { administration }\end{array}$ & Outcomes & References/country \\
\hline $\begin{array}{l}\text { Pure compound (Sigma } \\
\text { Aldrich) }\end{array}$ & $\begin{array}{l}\text { (-)-epigallocatechin- } \\
\text { 3-O-gallate }\end{array}$ & $\begin{array}{l}\text { In vivo Male Swiss } \\
\text { albino rats Single } \\
\text { injection of STZ } \\
\text { (55 mg/kg, i.p) }\end{array}$ & $\begin{array}{l}\text { No treatment } \\
\text { (-ve control) } \\
5 \text { weeks }\end{array}$ & $\begin{array}{l}25 \text { mg/kg/orally/ } \\
\text { once/daily after } \\
\text { fourth day diabetes } \\
\text { induction }\end{array}$ & $\begin{array}{l}\text { Reduce blood glucose } \\
\text { Increase Body weight } \\
\text { Improved serum lipids } \\
\text { profile } \\
\text { Ameliorated plasma } \\
\text { level of Nitric oxide (NO), } \\
\text { IL-6 and TNF-a level } \\
\text { Reduced diabetes- } \\
\text { induced hyperalgesia in } \\
\text { the behavioural tests } \\
\text { (hot plate, formalin, tail } \\
\text { immersion and } \\
\text { carrageenan-induced } \\
\text { oedema model) }\end{array}$ & $\begin{array}{l}\text { Egypt, (Abo-Salem } \\
\text { et al., 2020) }\end{array}$ \\
\hline $\begin{array}{l}\text { Pure compound (Sigma } \\
\text { Aldrich) }\end{array}$ & Catechin & $\begin{array}{l}\text { In vivo Male Sprague } \\
\text { Dawley rats. Single } \\
\text { injection of STZ } \\
\text { (55 mg/kg, i.p.) }\end{array}$ & $\begin{array}{l}\text { No treatment } \\
\text { (-ve control) } \\
28 \text { days }\end{array}$ & $\begin{array}{l}25 \mathrm{mg} / \mathrm{kg} \text { and } \\
50 \mathrm{mg} / \mathrm{kg} \text { orally after } \\
6 \text { weeks of diabetes } \\
\text { induction }\end{array}$ & $\begin{array}{l}\text { Reduce blood glucose } \\
\text { Increased body weight } \\
\text { Reduced } \\
\text { Malondialdehyde (MDA) } \\
\text { Increased glutathione } \\
\text { (GSH), catalase, } \\
\text { Superoxide } \\
\text { dismutase (SOD) } \\
\text { Reduced MMP-9 }\end{array}$ & $\begin{array}{l}\text { India, (Addepalli and } \\
\text { Suryavanshi, 2018) }\end{array}$ \\
\hline $\begin{array}{l}\text { Pure compound (Sigma } \\
\text { Aldrich) }\end{array}$ & Proanthocyanidin B2 & $\begin{array}{l}\text { In-vitro Dorsal root } \\
\text { ganglion neuron culture. } \\
\text { Incubated with } 45 \mathrm{mM} \\
\text { high-glucose }\end{array}$ & $\begin{array}{l}\text { Incubated in } \\
\text { neurobasal } \\
\text { medium (-ve } \\
\text { control) } 24 \mathrm{~h}\end{array}$ & $10 \mu \mathrm{g} / \mathrm{ml}$ & $\begin{array}{l}\text { Decreased } \\
\text { Neuronal ROS } \\
\text { Increased Neurite } \\
\text { outgrowth } \\
\text { Decreased apoptosis } \\
\text { Increased cell viability } \\
\text { increased GAP-43 } \\
\text { mRNA }\end{array}$ & $\begin{array}{l}\text { China, (Zhang et al., } \\
\text { 2018) }\end{array}$ \\
\hline $\begin{array}{l}\text { Pure compound } \\
\text { (Holliday and Co. } \\
\text { Canada) }\end{array}$ & $\begin{array}{l}\text { Epigallocatechin- } \\
\text { gallate }\end{array}$ & $\begin{array}{l}\text { In vivo Adult male Wistar } \\
\text { rats. Intraperitoneal (i.p.) } \\
\text { injection of STZ } \\
\text { ( } 60 \mathrm{mg} / \mathrm{kg} \text { body weight }\end{array}$ & $\begin{array}{l}\text { Injected with } \\
\text { citrate buffer } \\
\text { (-ve control) } \\
10 \text { weeks }\end{array}$ & $\begin{array}{l}2 \mathrm{~g} / \mathrm{L} \text { in drinking } \\
\text { water }\end{array}$ & $\begin{array}{l}\text { Not affected blood } \\
\text { glucose level } \\
\text { Not affected body } \\
\text { weight } \\
\text { Reduced 8-OHdG } \\
\text { immunoreaction } \\
\text { Reduced c-Fos IR } \\
\text { neurons in the spinal } \\
\text { cord } \\
\text { Amelioration of tactile } \\
\text { allodynia and } \\
\text { mechanical } \\
\text { hyperalgesia }\end{array}$ & $\begin{array}{l}\text { Portugal, (Raposo } \\
\text { et al., 2015) }\end{array}$ \\
\hline $\begin{array}{l}\text { Punica granatum L. } \\
\text { (Lythraceae) extract } \\
\text { (Ibn-Al-Nafess herbalist, } \\
\text { Beirut, Lebanon) }\end{array}$ & gallic acid & $\begin{array}{l}\text { In vivo Male Swiss- } \\
\text { Webster mice. Alloxan } \\
\text { (180 mg/kg) every } 48 \mathrm{~h} \\
\text { for } 3 \text { time }\end{array}$ & $\begin{array}{l}\text { Vehicle (0.9\% } \\
\text { sterile saline } \\
\text { (-ve control) } \\
1 \text { day (acute) } \\
\text { and } 7 \text { days } \\
\text { (subacute) }\end{array}$ & $\begin{array}{l}25,50 \text {, and } \\
100 \mathrm{mg} / \mathrm{kg} \text {, i.p after } \\
\text { fourth day diabetes } \\
\text { induction }\end{array}$ & $\begin{array}{l}\text { Reduce blood glucose } \\
\text { Increase Body weight } \\
\text { Rise serum catalase } \\
\text { activity } \\
\text { Improvement in hot } \\
\text { plate latency } \\
\text { Improvement in tail-flick } \\
\text { latency }\end{array}$ & $\begin{array}{l}\text { Lebanon, (Raafat and } \\
\text { Samy, 2014) }\end{array}$ \\
\hline
\end{tabular}

(Continued on following page) 
TABLE 1 | (Continued) Characteristic of included studies.

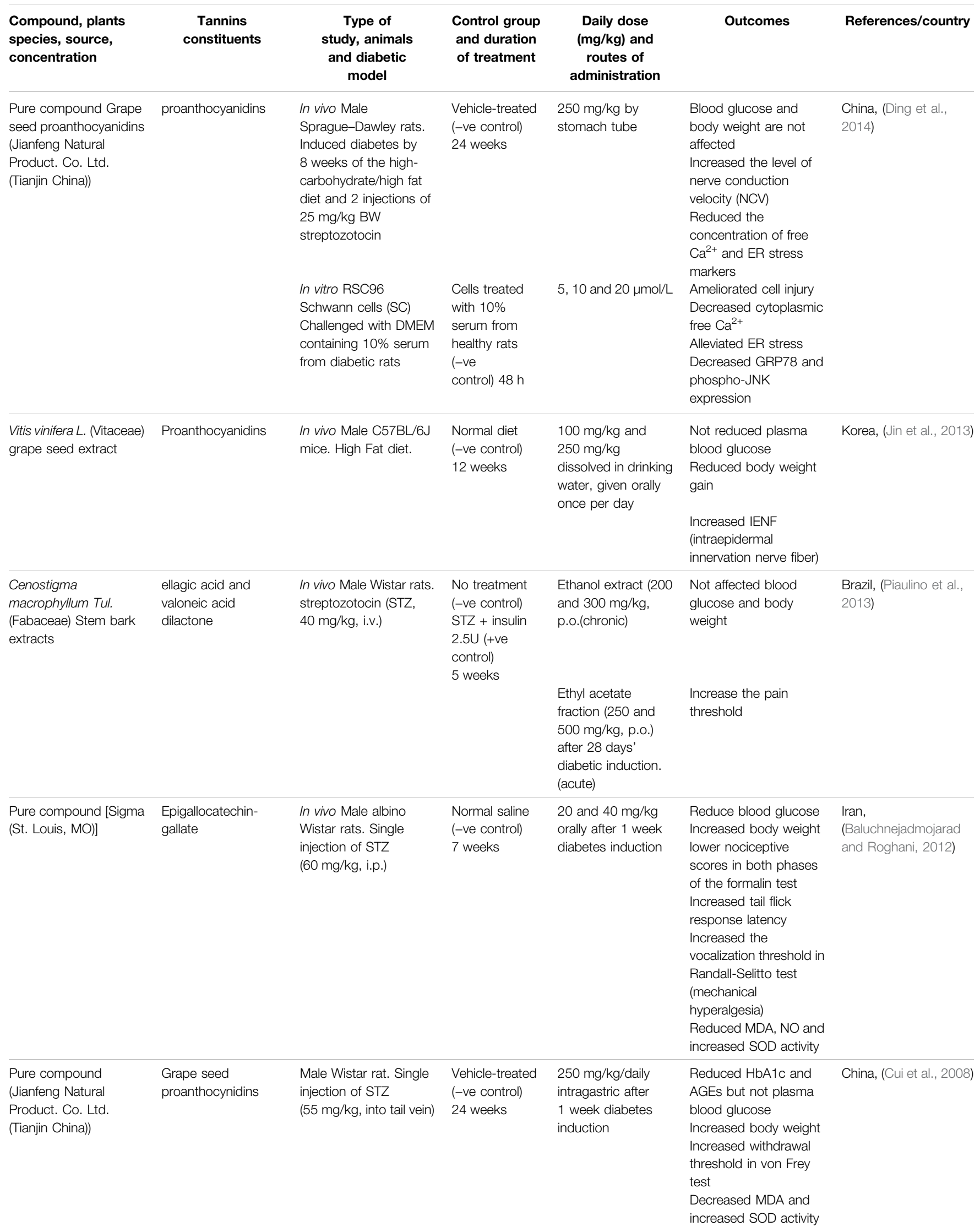


TABLE 2 | The plants botanical and chemical composition.

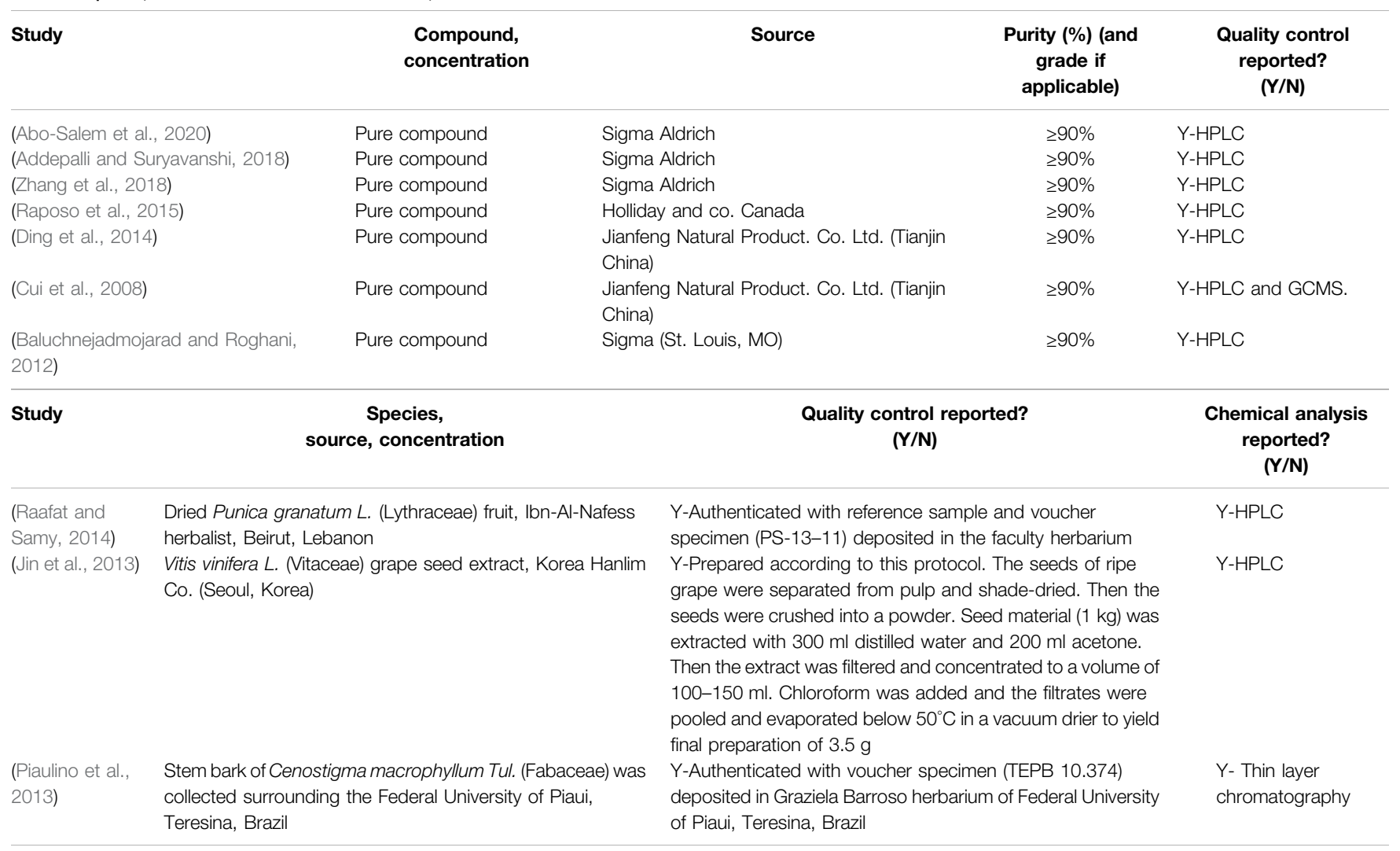

TNF- $\alpha$ were reduced (Abo-Salem et al., 2020). When given orally at dosages of $25 \mathrm{mg} / \mathrm{kg}$ and $50 \mathrm{mg} / \mathrm{kg}$ for 28 days, catechin can reduce matrix metalloproteinase-9 (MMP-9) levels (Addepalli and Suryavanshi, 2018). Raposo et al. (2015) discovered that EGCC at a dose of $2 \mathrm{~g} / \mathrm{L}$ in drinking water for 10 weeks decreased Fos IR neurons in male Wistar rats, a marker for nociceptive response.

In addition to their anti-inflammatory properties, phytochemical tannins play a crucial role in preventing DNP because of their antioxidant activity. Catechin $(25 \mathrm{mg} / \mathrm{kg}$ and $50 \mathrm{mg} / \mathrm{kg}$ orally for 28 days) decreased malondialdehyde (MDA) but raised the reduced glutathione (GSH), catalase, and superoxide dismutase (SOD) levels in STZ-induced diabetic rats (Addepalli and Suryavanshi, 2018). Baluchnejadmojarad and Roghani (2012) and Cui et al. (2008) investigations also revealed comparable impact. In STZ-induced diabetes, in male albino Wistar rats, treatment with EGCG (20 and $40 \mathrm{mg} / \mathrm{kg} \mathrm{BW}$ orally) for 7 weeks decreased blood MDA and NO levels while increasing SOD level (Baluchnejadmojarad and Roghani, 2012). In STZ-induced diabetic male Wistar rats, grape seed proanthocynidins $(250 \mathrm{mg} / \mathrm{kg} /$ daily intragastric $)$ therapy for 24 weeks decreased plasma MDA and elevated SOD levels (Cui et al., 2008). Raposo et al. (2015) found that early treatment with EGCG decreased the 8-hydroxy-21deoxyguanosine (8-OHdG) immunoreaction, preventing oxidative stress damage (Raposo et al., 2015).

In tunicamycin-treated sciatic nerves and rat Schwann cells (RSC cells), administration of proanthocyanidin and its metabolites catechin and epicatechin decreased cell damage. It downregulated the expression level of endoplasmic reticulum (ER) stress proteins (Ding et al., 2014). Schwann cells (SC) create lipid-rich myelin sheaths to extend their plasma membrane to conduct the action potential along axons and maintain axonal integrity (Eckersley, 2002). SC must generate many myelin membrane proteins, cholesterol, and membrane lipids through the secretory route during the active phase of myelination (Clague and Hammond, 2006). Demyelination and axonal degeneration, which are early stages of DNP, can be caused by disruptions in the secretory system, dependent on ER homeostasis (Lin and Popko, 2009).

Treatment with phytochemical tannins has also been shown to help with DNP hyperalgesia and allodynia symptoms. Its antiinflammatory, antioxidant, and antihyperalgesic properties are thought to be the mechanism for decreasing these symptoms (Stott and Marino, 2020). According to Abo-Salem et al. (2020), treatment with EGCG alleviated hyperalgesia responses indicated 
by a hot plate, tail immersion, formalin, and carrageenaninduced oedema tests in STZ-induced diabetic rats. After being treated with EGCG for 10 weeks, STZ-induced diabetics also had a higher paw withdrawal threshold (PWT), indicating that tactile allodynia and mechanical hyperalgesia had improved (Raposo et al., 2015). In diabetic rats, chronic EGCG therapy $(40 \mathrm{mg} / \mathrm{kg})$ dramatically reduced hyperalgesia (formalin test, hot tail immersion test, and paw pressure test) as compared to untreated diabetics (Baluchnejadmojarad and Roghani, 2012). In the hot plate and tail-flick tests, Punica granatum L. (Lythraceae) extract significantly reduced thermal and tailflick latency in alloxan-induced diabetic mice (Raafat and Samy, 2014). Piaulino et al. (2013) found that treating diabetic Wistar rats with stem bark extracts of Cenostigma macrophyllum Tul.(Fabaceae) raised mechanical nociceptive threshold (MNT) by using von Frey filaments as compared to untreated diabetic rats. In diabetic rats, grape seed proanthocyanidin extract can also reduce mechanical allodynia by the von Frey test (Cui et al., 2008).

\section{STRENGTH AND LIMITATION}

This study offers a thorough evaluation of research progress on tannins and their efficacy in the treatment of symptomatic DNP. Tannins have been shown to alleviate the hyperalgesia and allodynia symptoms associated with DNP through their antiinflammatory, antioxidant, and antihyperalgesic properties. We discovered the most relevant articles since we took a thorough approach with all search keywords. This study can be used as a baseline to offer information regarding the efficacy of tannins as a therapeutic therapy for symptomatic DNP. Phytochemical tannins have anti-inflammatory, antioxidant, and antihyperalgesic properties to help with the hyperalgesia and allodynia symptoms of DNP. However, we could not draw any definitive findings because of the small sample size. Attempts to re-investigate also fell short of including new tannins and DNP treatment data.

There are limitations to the research conducted thus far to examine the potential of tannins in DNP. The drawback of the tannins studies and their efficacy on symptomatic DNP was that some of the models employed did not entirely replicate the DNP condition. Zhang et al. (2018) employed DRG culture in high glucose conditions, which did not accurately imitate the situation of DNP in vivo. In-vivo trials, on the other hand, lacked a control group that was treated with current medications authorised to treat symptomatic DNP for comparison. Many research intended to lower blood glucose levels and increase body weight, primarily the type 1 diabetes model but did not compare their findings to those treated with metformin and insulin. Metformin and insulin are the medication taken by the diabetic patient to control their glucose level in the blood. Tannins anti-inflammatory, antioxidant, and antihyperalgesic properties are also not comparable to those of other approved drugs such as duloxetine, pregabalin, and tapentadol (Freeman, 2013).

Tannins research as a possible symptomatic DNP therapy has yet to identify a specific molecular basis for its anti-inflammatory, antioxidant, and antihyperalgesic properties. Only Zhang et al. (2018) proposed that the PI3K/Akt signalling pathway was engaged in the neurotoxicity of high glucose conditions in DRG culture. Furthermore, most research concentrates exclusively on behaviour analysis and changes in inflammatory markers, with a little examination into molecular changes in the expression of specific genes, proteins, and receptors along the pain pathway, which begins in the peripheral nervous system and ends in the brain. There is no evidence on whether tannins can modify these specific genes, proteins, and receptors to decrease DNP symptoms. Furthermore, no toxicological studies have been conducted to examine the toxicities of tannins on liver and kidney biochemical markers.

\section{PRIORITIES FOR FUTURE RESEARCH}

A future investigation on tannins and their efficacy on DNP symptoms should reveal a precise molecular mechanism for their anti-inflammatory, antioxidant, and antihyperalgesic effects along the pain pathway. To investigate the effectiveness of tannins, a suitable in vitro and in vivo model to simulate the situation at the periphery, spinal cord, and brain during DNP and changes in particular genes, proteins, and receptors when treated with tannins, is required. In treating DNP symptoms, a specific molecular pathway connected to anti-inflammatory, antioxidant, and antihyperalgesic properties of tannins must be targeted and investigated to elucidate its molecular function better. A comparison of the effects of tannins and approved drugs on DNP symptoms is also required to see whether tannins' results are equal or even superior to all of these treatments. Because the aetiology of DNP includes multiple elements and pathways, a combination of medications may be effective.

\section{CONCLUSION}

Tannins, a phytochemical, help to alleviate DNP symptoms. These results are due to its hypoglycaemic effect, most visible in type 1 diabetic rats but not in type 2 diabetic rats. Phytochemical tannins lower blood glucose levels while increasing body weight in insulin insufficiency (type 1 diabetes), but not in insulin resistance or hyperlipidaemia studies (type 2 diabetes). Phytochemical tannins can be used as an anti-inflammatory, antioxidant, and antihyperalgesic to help with the hyperalgesia and allodynia symptoms of DNP. Tannins, a phytochemical, might potentially be used to treat DNP. However, we could not make definitive conclusions because of the limited sample size and limitations of the studies conducted. Before tannins may be employed as 
therapeutic agents for DNP, more study is needed to establish the specific molecular mechanism for all of these tannins properties along the pain pathway and examine the side effects of tannins in the treatment of DNP.

\section{DATA AVAILABILITY STATEMENT}

The original contributions presented in the study are included in the article/Supplementary Materials, further inquiries can be directed to the corresponding author.

\section{REFERENCES}

Ab Hamid, N., Omar, N., Ismail, C. A. N., and Long, I. (2021). Insight of Mechanism and Signaling Pathway in Pathogenesis of Diabetic Neuropathy: A Review. IIUM Med. J. Malaysia 20 (4), 95-103. doi:10.31436/ imjm.v20i4.1947

Abo-Salem, O. M., Ali, T. M., Harisa, G. I., Mehanna, O. M., Younos, I. H., and Almalki, W. H. (2020). Beneficial Effects of (-)-Epigallocatechin-3-O-Gallate on Diabetic Peripheral Neuropathy in the Rat Model. J. Biochem. Mol. Toxicol. 34 (8), e22508. doi:10.1002/jbt.22508

Addepalli, V., and Suryavanshi, S. V. (2018). Catechin Attenuates Diabetic Autonomic Neuropathy in Streptozotocin Induced Diabetic Rats. Biomed. Pharmacother. 108 (July), 1517-1523. doi:10.1016/j.biopha.2018.09.179

Ajebli, M., and Eddouks, M. (2018). The Promising Role of Plant Tannins as Bioactive Antidiabetic Agents. Curr. Med. Chem. 26 (25), 4852-4884. doi:10.2174/0929867325666180605124256

Akude, E., Zherebitskaya, E., Chowdhury, S. K., Smith, D. R., Dobrowsky, R. T., and Fernyhough, P. (2011). Diminished Superoxide Generation Is Associated with Respiratory Chain Dysfunction and Changes in the Mitochondrial Proteome of Sensory Neurons from Diabetic Rats. Diabetes 60 (1), 288-297. doi:10.2337/ db10-0818

Baluchnejadmojarad, T., and Roghani, M. (2012). Chronic Oral EpigallocatechinGallate Alleviates Streptozotocin-Induced Diabetic Neuropathic Hyperalgesia in Rat: Involvement of Oxidative Stress. Iran J. Pharm. Res. 11 (4), 1243-1253.

Chowdhury, S. K., Zherebitskaya, E., Smith, D. R., Akude, E., Chattopadhyay, S., Jolivalt, C. G., et al. (2010). Mitochondrial Respiratory Chain Dysfunction in Dorsal Root Ganglia of Streptozotocin-Induced Diabetic Rats and its Correction by Insulin Treatment. Diabetes 59 (4), 1082-1091. doi:10.2337/ db09-1299

Clague, M. J., and Hammond, D. E. (2006). Membrane Traffic: Catching the Lysosome Express. Curr. Biol. 16 (11), R416-R418. doi:10.1016/ j.cub.2006.05.009

Cui, X. P., Li, B. Y., Gao, H. Q., Wei, N., Wang, W. L., and Lu, M. (2008). Effects of Grape Seed Proanthocyanidin Extracts on Peripheral Nerves in StreptozocinInduced Diabetic Rats. J. Nutr. Sci. Vitaminol (Tokyo) 54 (4), 321-328. doi:10.3177/jnsv.54.321

Ding, Y., Dai, X., Zhang, Z., Jiang, Y., Ma, X., Cai, X., et al. (2014). Proanthocyanidins Protect against Early Diabetic Peripheral Neuropathy by Modulating Endoplasmic Reticulum Stress. J. Nutr. Biochem. 25 (7), 765-772. doi:10.1016/j.jnutbio.2014.03.007

Eckersley, L. (2002). Role of the Schwann Cell in Diabetic Neuropathy. Int. Rev. Neurobiol. 50 (February), 293-321. doi:10.1016/s0074-7742(02)50081-7

Feldman, E. L., Nave, K. A., Jensen, T. S., and Bennett, D. L. H. (2017). New Horizons in Diabetic Neuropathy: Mechanisms, Bioenergetics, and Pain. Neuron 93 (6), 1296-1313. doi:10.1016/j.neuron.2017.02.005

Freeman, R. (2013). New and Developing Drugs for the Treatment of Neuropathic Pain in Diabetes. Curr. Diab Rep. 13 (4), 500-508. doi:10.1007/s11892-0130396-6

Gylfadottir, S. S., Weeracharoenkul, D., Andersen, S. T., Niruthisard, S., Suwanwalaikorn, S., and Jensen, T. S. (2019). Painful and Non-painful

\section{AUTHOR CONTRIBUTIONS}

IL provided funding and prepared the manuscript, while CI and NO proofread this manuscript.

\section{FUNDING}

This study was supported by the Fundamental Research Grant Scheme (FRGS) Ministry of Higher Education Malaysia (No. FRGS/1/2020/SKK0/USM/03/5).

Diabetic Polyneuropathy: Clinical Characteristics and Diagnostic Issues. J. Diabetes Investig. 10 (5), 1148-1157. doi:10.1111/jdi.13105

Ismail, C. A. N., Suppian, R., Ab Aziz, C. B., and Long, I. (2020). Expressions of Spinal Microglia Activation, BDNF, and DREAM Proteins Correlated with Formalin-Induced Nociceptive Responses in Painful and Painless Diabetic Neuropathy Rats. Neuropeptides 79, 102003. doi:10.1016/ j.npep. 2019.102003

Jin, H. Y., Cha, Y. S., Baek, H. S., and Park, T. S. (2013). Neuroprotective Effects of Vitis vinifera Extract on Prediabetic Mice Induced by a High-Fat Diet. Korean J. Intern. Med. 28 (5), 579-586. doi:10.3904/kjim.2013.28.5.579

Kim, B., and Feldman, E. L. (2012). Insulin Resistance in the Nervous System. Trends Endocrinol. Metab. 23 (3), 133-141. doi:10.1016/j.tem.2011.12.004

Laddha, A. P., and Kulkarni, Y. A. (2019). Tannins and Vascular Complications of Diabetes: An Update. Phytomedicine 56 (August 2018), 229-245. doi:10.1016/ j.phymed.2018.10.026

Lawrence, T. (2009). The Nuclear Factor NF-kappaB Pathway in Inflammation. Cold Spring Harb Perspect. Biol. 1 (6), a001651-11. doi:10.1101/ cshperspect.a001651

Lin, W., and Popko, B. (2009). Endoplasmic Reticulum Stress in Disorders of Myelinating Cells. Nat. Neurosci. 12 (4), 379-385. doi:10.1038/ nn. 2273

Liu, T., Zhang, L., Joo, D., and Sun, S. C. (2017). NF-кB Signaling in Inflammation. Signal. Transduct Target. Ther. 2 (March). doi:10.1038/ sigtrans.2017.23

Meng, J. M., Cao, S. Y., Wei, X. L., Gan, R. Y., Wang, Y. F., Cai, S. X., et al. (2019). Effects and Mechanisms of tea for the Prevention and Management of Diabetes Mellitus and Diabetic Complications: An Updated Review. Antioxidants (Basel) 8 (6), 170. doi:10.3390/antiox 8060170

Piaulino, C. A., Carvalho, F. C., Almeida, B. C., Chaves, M. H., Almeida, F. R., and Brito, S. M. (2013). The Stem Bark Extracts of Cenostigma macrophyllum Attenuates Tactile Allodynia in Streptozotocin-Induced Diabetic Rats. Pharm. Biol. 51 (10), 1243-1248. doi:10.3109/13880209.2013.786096

Raafat, K., and Samy, W. (2014). Amelioration of Diabetes and Painful Diabetic Neuropathy by Punica Granatum L. Extract and its spray Dried Biopolymeric Dispersions. Evid. Based Complement. Alternat Med. 2014, 180495. doi:10.1155/2014/180495

Raposo, D., Morgado, C., Pereira-Terra, P., and Tavares, I. (2015). Nociceptive Spinal Cord Neurons of Laminae I-III Exhibit Oxidative Stress Damage during Diabetic Neuropathy Which Is Prevented by Early Antioxidant Treatment with Epigallocatechin-Gallate (EGCG). Brain Res. Bull. 110, 68-75. doi:10.1016/ j.brainresbull.2014.12.004

Srinivasan, K., Viswanad, B., Asrat, L., Kaul, C. L., and Ramarao, P. (2005). Combination of High-Fat Diet-Fed and Low-Dose Streptozotocin-Treated Rat: A Model for Type 2 Diabetes and Pharmacological Screening. Pharmacol. Res. 52 (4), 313-320. doi:10.1016/j.phrs.2005.05.004

Stott, N. L., and Marino, J. S. (2020). High Fat Rodent Models of Type 2 Diabetes: From Rodent to Human. Nutrients 12 (12), 1-19. doi:10.3390/ nu12123650

Tesfaye, S., Boulton, A. J., and Dickenson, A. H. (2013). Mechanisms and Management of Diabetic Painful Distal Symmetrical Polyneuropathy. Diabetes Care 36 (9), 2456-2465. doi:10.2337/dc12-1964 
Uddin, M. S., Mamun, A. A., Rahman, M. A., Kabir, M. T., Alkahtani, S., Alanazi, I. S., et al. (2020). Exploring the Promise of Flavonoids to Combat Neuropathic Pain: From Molecular Mechanisms to Therapeutic Implications. Front. Neurosci. 14 (June), 478-518. doi:10.3389/ fnins.2020.00478

Vincent, A. M., Russell, J. W., Low, P., and Feldman, E. L. (2004). Oxidative Stress in the Pathogenesis of Diabetic Neuropathy. Endocr. Rev. 25 (4), 612-628. doi:10.1210/er.2003-0019

Wang, D., Couture, R., and Hong, Y. (2014). Activated Microglia in the Spinal Cord Underlies Diabetic Neuropathic Pain. Eur. J. Pharmacol. 728 (1), 59-66. doi:10.1016/j.ejphar.2014.01.057

Zhang, Y. P., Liu, S. Y., Sun, Q. Y., Ren, J., Liu, H. X., and Li, H. (2018). Proanthocyanidin B2 Attenuates High-Glucose-Induced Neurotoxicity of Dorsal Root Ganglion Neurons through the PI3K/Akt Signaling Pathway. Neural Regen. Res. 13 (9), 1628-1636. doi:10.4103/16735374.237174
Conflict of Interest: The authors declare that the research was conducted in the absence of any commercial or financial relationships that could be construed as a potential conflict of interest.

Publisher's Note: All claims expressed in this article are solely those of the authors and do not necessarily represent those of their affiliated organizations, or those of the publisher, the editors and the reviewers. Any product that may be evaluated in this article, or claim that may be made by its manufacturer, is not guaranteed or endorsed by the publisher.

Copyright (๑) 2022 Omar, Ismail and Long. This is an open-access article distributed under the terms of the Creative Commons Attribution License (CC BY). The use, distribution or reproduction in other forums is permitted, provided the original author(s) and the copyright owner(s) are credited and that the original publication in this journal is cited, in accordance with accepted academic practice. No use, distribution or reproduction is permitted which does not comply with these terms. 